\title{
FINANCING METROPOLITAN AREAS IN BRAZIL POLITICAL, INSTITUTIONAL AND LEGAL OBSTACLES AND EMERGENCE OF NEW PROPOSALS FOR IMPROVING COORDINATION*
}

\author{
Fernando Rezende
}

Sol Garson ${ }^{* *}$

\begin{abstract}
As of the 1988 Constitution, the states, by means of a constitutional amendment, may establish metropolitan regions in order to integrate the organization, planning and operation of public functions of common interest of the states and their respective municipalities. Despite some attempts to overcome financial troubles through better coordination of public actions - new proposals for dealing with a more constrained financial situation - , difficulties of institutional character and the fragmentation of the available resources did not allow for significant improvements to be made to date. This paper intends to provide a background to understanding the problems of metropolitan financing in Brazil, which is necessary to deal with the obstacles still existing to the improvement of investments financing and service provision.
\end{abstract}

Key words: metropolitan regions, investments financing, institutional obstacles

JEL Code: H - Public Economics, H77 - Intergovernmental Relations; Federalism

* Paper received on August $22^{\text {th }}, 2004$, and approved on December 15 $5^{\text {th }}, 2005$. Support from the Forum of Federations made this study possible. Present version was adapted for publication.

** Economist, professor at the Brazilian School of Public Administration Getúlio Vargas Foundation, email: Fernando.Rezende@desenvolvimento.gov.br

*** Economist, PhD student in Urban and Regional Research and Planning at IPPUR/UFRJ, consultant in Government Finance and Budgeting, e-mail: sgarson@terra.com.br 


\section{O FINANCIAMENTO DE ÁREAS METROPOLITANAS NO BRASIL: OBSTÁCULOS POLÍTICOS, INSTITUCIONAIS E JURÍDICOS E NOVAS PROPOSTAS PARA MELHORAR A COORDENAÇÃO}

RESUMO Desde a Constituição de 1988, os estados, por meio de legislação complementar a suas próprias constituições, podem estabelecer regiões metropolitanas para integrar a organização, planejamento e operação de funções públicas de interesse comum dos estados e seus respectivos municípios. Apesar de algumas tentativas para superar dificuldades financeiras com uma coordenação mais eficaz de ações públicas - mediante novas propostas para lidar com uma situação financeira de maior rigidez —, dificuldades de ordem institucional e a fragmentação dos recursos disponíveis impediram qualquer melhoria significativa. Este artigo busca oferecer um pano de fundo para a compreensão dos problemas relativos ao financiamento metropolitano no Brasil, de forma a fazer face aos entraves à ampliação do financiamento de investimentos e da prestação de serviços nessas áreas.

Palavras-chave: regiões metropolitanas, financiamento de investimentos, obstáculos institucionais 


\section{INTRODUCTION}

The unstable macroeconomic scenario of the past two decades and the fiscal and monetary policies adopted to deal with this situation contributed to disrupt the Brazilian metropolitan finances. On the fiscal side, hard budgetary constraints led to a virtual disappearance of public savings at all levels of the Brazilian federation. On the monetary field, the persistence of high interest rates for quite a long time, together with tough limits for state and local government access to loans granted by federal financial institutions, narrowed the way to overcome budgetary constraints through additional borrowing.

At the same time, low levels of economic growth and high degrees of income inequalities did not set a favorable environment for a more active role of the private sector in financing infrastructure investments and service provision in metropolitan areas. With the sole exception of transportation, regulatory uncertainties, as well as limitations for applying tariffs that simultaneously met the requirements of private investors and the purchasing power of the population, did not leave room for the advance of concessions and/or privatizations.

These already unfavorable conditions got worse after the success of the stabilization plan put into place in 1994: the Real Plan. The end of an era of high inflation rates meant more difficulties in managing fiscal accounts, which could no longer benefit from the watering effect of high inflation rates that helped curb budgetary disequilibrium, since tax revenues were fully indexed into the inflation rate, while public expenditures were not. Furthermore, the consolidation of a stable currency under external financial shocks asked for a tighter monetary policy and even higher interest rates, which increased the burden of the public debt and cut the public sector's access to borrowing.

The disruption of the metropolitan finances severely affected $42 \%$ of the Brazilian population (71 million people) who live in 26 metropolitan regions. Low income families had their access to basic services denied, due to the fall in public investments. Living conditions suffered from the deterioration of the urban infrastructure and of the quality of urban services, which also affected the competitiveness of the major metropolitan cities due to traffic congestion, pollution and criminality. 
Despite some attempts to overcome financial troubles through a better coordination of public actions, the fragmentation of the available resources did not allow for significant improvements to be made to date. Indeed, the consolidation of these attempts to improve coordination (see section 6) may be jeopardized if financial needs are not properly met.

The next section highlights some institutional aspects in place when metropolitan regions were legally recognized in Brazil, in the seventies. The background to better understanding the problems of metropolitan financing is the subject of the second section. The third section presents the structure of metropolitan finance, and introduces the following issue, relating to the main obstacles to improving the financing of investments and service provision in metropolitan areas. Section five provides a description of new proposals for dealing with a more constrained financial situation. Some concluding remarks are added at the end.

\section{INSTITUTIONAL ASPECTS OF METROPOLITAN REGIONS}

By the year 2000, the rate of urbanization had reached $81.2 \%$ of the Brazilian population of 170 million people. The least urbanized region, the Northeast, already had $69 \%$ of its population living in urban areas. That was not the case in the beginning of the sixties, when only $44.7 \%$ of the total population of 70 million people lived in those areas. The Southeast region was the most highly urbanized - with $57 \%$ of the population being classified as urban.

Brazil stood under a military regime from 1964 to 1985. From 1968 to 1976, the country experienced fast economic growth, accompanied by intense urbanization. In that period, annual economic growth was higher than $8 \%$, with the sole exception of 1975. In 1980, urbanization had reached $67.6 \%$ of the total population. Spatial concentration of economic growth meant spatial concentration of the population, raising the discussion of the metropolitan issue. In fact, several institutions in society had long been concerned with the acceleration of urbanization. In 1963, the Brazilian Institute of Architects and the Institute for Social Security and Assistance of State Workers had proposed the creation of institutions to gather municipalities to deal with common problems related to the provision of public services. 
At the central government level, urban policy was under the responsibility of public companies, with the guarantee of funding and speed in its allocation. The articulation of urban sector programs in space should count on special organs, among other instruments, to manage the metropolitan regions. Although metropolitan regions had legally come to existence through the Constitution of 1967, it took seven years to pass amendment n. 14/73, which defined eight metropolitan regions and their constituent municipalities. The amendment specified, among other things, services of common interest, regardless of regional differences, the structure of management, and the mechanisms of programs and projects administration. It gave priority to the use of central and state funds, including loans, to municipalities that participated in integrated projects and services.

In assigning to the Union competence for creating metropolitan regions, the central government reasserts its power over the more developed regions of the country. Araújo points out the contradictions in the federal government's actions. Although it aimed at creating an institutional instrument for urban planning and integrated development, the allocation of resources was influenced by political alliances and the interests of sectors that found space in the fragmentation of the administration of the Brazilian State. ${ }^{1}$ Demands from "clients" were sometimes disguised in new clothing of technical studies, conducted by State bureaucracies, responding to the demands of the executive power of the states.

The difficulty in developing projects adapted to specific regional demands, the lack of a forum for the municipal constituents to discuss their demands, and the political and economic crisis at the turn of the seventies seriously weakened this system of metropolitan administration.

With the political crisis in the military regime, the focus on planning was lost, and the funds for urban areas became increasingly scarce. In the eighties, Brazil suffered through a series of plans to stabilize the economy, in an attempt to bring the macroeconomic situation under control. Between the periodic crises, episodic inflation sometimes raced out of control, eroding not only the currency and the ability to plan, but also rendering the budgetary instruments useless. A new attempt to define an institutional basis for dealing with the metropolitan regions was made when the Constitution of 1988 was drawn. 


\section{BASIC FACTS CONCERNING METROPOLITAN FINANCING}

The decentralization drive of the Constitution of 1988 carried with it important implications for metropolitan finances. First, the responsibility for creating and organizing metropolitan areas in Brazil was transferred from the federal government to the states. Second, changes in the fiscal federal system implied greater autonomy for state and local governments to collect taxes and to dispose of the portion of major central taxes shared with them. Third, municipalities were recognized as members of the Federation with a similar status as the one held by the states.

Despite the growth in available revenue - the municipal share rose to $16.1 \%$ in 2003 , up from the $10.8 \%$ of the fiscal pie they had in 1988 - the resources were clearly inadequate to meet the needs of urban development. This assertion becomes even more important as problems caused by accelerated urbanization worsened. In 2004, 76.7 million people $-42.4 \%$ of the population - lived in metropolitan regions in Brazil, in an environment of blatant inequality. In the major cities, the general indicators currently used do not show the extent of the contrasts. Although the core cities in the metropolitan regions are the richest areas in the country, they are those where intra-urban inequality is greatest.

The supply of public goods and services - based on tax revenues and, within a federal system, on intergovernmental transfers - may compensate for, or at least reduce, the losses from interjurisdictional externalities. In less developed countries, the design of such a system is at the heart of efforts to reduce spatial and interpersonal income differences. Besides these resources, capital expenditures may be financed through public debt. Since the benefits of these projects will be distributed over several generations, the benefits principle suggests that it will be up to future generations to pay for a share of those loans.

As of 1988, the states, by means of a constitutional amendment, may establish metropolitan regions ${ }^{2}$ in order to integrate the organization, planning and operation of public functions of common interest of the states and their respective municipalities. Insofar as the states cannot interfere in municipal autonomy, the institutions created to oversee activities of common interest have just administrative and not political character, which means lack of legislative power. Notwithstanding, some specialists understand that 
the participation of municipalities in a metropolitan region, once it is created, is compulsory, since the local administration could not refuse to cooperate in matters of common interest. (Alves, 1998)

Apart from the controversy over the legal obligations of the new constitutional provision, the transfer of the responsibility for the institution of metropolitan regions to the states was politically inconsistent with the new status of the municipalities in the Brazilian federation, as one of the basic reasons for the institutionalization of metropolitan areas is the need for coordinating investments and integrating the provision of public services throughout these regions. Without effective means to enforce coordination, state governments cannot lead the efforts to avoid conflicting policies and overlapping. The lack of conditions for coordination is exacerbated in times of conflicting political affiliations between the state governor and the mayor of the main metropolitan city, as both compete for greater influence in the whole region.

Changes in the Brazilian fiscal federalism increased the political and administrative autonomy of the municipalities: disposable revenues share rose to $16.6 \%$ in 2002 , up from the $10.8 \%$ portion of the fiscal pie they had in 1988 . Nevertheless, this increase was not evenly distributed. Due to criteria built into the formula for distributing the municipality's share in federal tax collections, bigger cities got a disproportionately smaller amount. Besides, the move of major manufacturing plants out of the metropolitan nucleus, in search of better conditions in terms of land prices and proximity of the working force, also contributed to weaken the budget of the core city in the metropolitan regions. The local tax base of these cities also suffered from the dislocation of financial, information and other services, whose firms moved out of the core cities, in search of lower tax on service rates (see box 1, Annex).

The complexities of the Brazilian fiscal federalism explain the huge unbalance in the distribution of fiscal resources in metropolitan areas. In general, the variables that affect the budget structure and size of individual municipalities in a given area are the following:

- the size and composition of the economic base;

- the size of the population;

- being or not a state capital;

- the multiplicity of federal transfers and the ability to fulfill the conditions attached to them. 
Putting it in simpler terms, municipalities with an important manufacturing sector and a small population have per capita budgets several times higher than the regional average, due to their share in the state's tax collections. At the other extreme, municipalities with a very large population and a fragile economy, usually functioning as a dormitory city, are severely under-financed, having per capita budgets well below the regional average. The city of Nova Iguaçu, with 780 thousand inhabitants, in the metropolitan region of Rio de Janeiro, has a total per capita revenue of only $\mathrm{R} \$ 373.00$. Medium size cities may benefit from federal redistributive transfers, but are rarely able to collect enough taxes to form a reasonable budget (see table 2). The case of the state capital city in the region varies according to its importance. Some of the major metropolitan cities can use local taxes to compensate for their small participation in shared revenues (Rio de Janeiro and São Paulo, in the Southeast), but the same is not true for other capital cities in less developed regions (Belém, in the North, and Fortaleza, in the Northeast).

In reality, though, the different conditions attached for receiving federal money outside the revenue sharing system make the situation of municipal finances much more complex. The money transferred outside the revenue sharing system can be placed into three categories: compensation, intergovernmental cooperation and discretionary transfers. The first refers to compensation for exemption granted to exports from the state tax and for the exploitation of natural resources (see box 2 for details).

Health and elementary education are the main services for which there are specific norms for intergovernmental cooperation in financing. Regarding elementary education, a special fund was created to guarantee a minimal amount of spending per student enrolled in public schools. Regarding health services, transfers from the federal government are related to the population and to the nature of services provided. In both cases, therefore, the money is allocated according to the spatial concentration of the education and health networks inside the metropolitan areas. The state capital and richer municipalities in the area are thus likely to get more money from these transfers, but they are usually required to provide services for the population of neighboring cities, specially the more sophisticated (and thus more expensive) health services. 
Discretionary transfers from the federal and state budgets can also help the financing of other social services carried out at the local level — childhood assistance and environment protection among them -, as well as small-scale investments in urban projects selected by local authorities. Insofar as these transfers depend not only on the effort of the states' representatives in the national parliament to include provisions on the annual budget, but also on the control of the Federal Treasury over the disbursement of these resources, they are uncertain and unstable, besides being politically sensitive.

The variety of sources and the distinct criteria that determine the transfer of federal money to the municipalities contribute to the mismatch of resources and responsibilities in the metropolitan areas. Two additional problems are the degree of sensibility to the economic cycle and the low degree of freedom with respect to the allocation of the municipal budgets. At the same time that a slow down in the level of economic activity increases unemployment and puts more pressure on the local governments, its effect on federal revenues and on the ability to raise funds from municipal taxes reduces the financial capabilities of the cities. On the expenditure side of the budget, earmarking of revenues and the legal obligation to service the debt leave little room for adjusting public spending according to changing priorities within the region.

The most important recent event from the viewpoint of the management of public finances in Brazil was the advent of the Fiscal Responsibility Law (LRF). Enacted in the year 2000, this law is recognized as an important advance in the direction of consolidating the adjustment of fiscal accounts in the federation. Basic provisions, such as those covering public planning, transparency, control and accountability, apply to the Executive branch across the federation - including public enterprises dependent on budgetary funds, special agencies and public foundations - , as well as to the Legislative and the Judiciary. Some of its major statements relate to:

- consistency of the annual budget and the multiyear plan (four years) and integration of budgetary and financial management;

- definition of permanent expenditures, for which stable resources must be put in place to avoid structural deficits;

- prohibition of new investments being created without provisions for covering operating costs; 
- compensation for new long-term commitments of budgetary resources by an equal reduction in previous assignments or by an unforeseen revenue increase;

- sequestration mechanisms: during the fiscal year, if either an unexpected shortage of revenue or an additional need to spend are envisaged, assigned budgetary resources have to be canceled in order to assure the achievement of fiscal targets set for the year;

- limitation of personnel expenditures to $60 \%$ of current revenues;

- adoption of a broad definition for the public debt to include operations such as short-term loans for anticipating the yearly revenues. Debt renegotiation among different levels of government is prohibited to eliminate prospects of recurrent bailouts. According to the Federal Constitution, the Senate establishes the limits and conditions for the public debt. Under present conditions, total municipal debt cannot exceed 1.2 times current revenues. Debt servicing costs and amortization payments, as well as new debt incurred during any fiscal year, are also subject to limits.

The LRF is an important landmark in the effort to introduce fiscal discipline at all levels of the Brazilian public administration. Nevertheless, it depends on a continuing effort by society inhibiting attempts to change the rules, particularly those relating to debt control. Even though the law may create additional constraints for metropolitan finances in the short run, in the medium and long run, it shall contribute to the restoration of public savings and to the opening up of new possibilities for increasing the participation of the private sector in the financing and provision of urban services.

\section{STRUCTURE OF METROPOLITAN FINANCING}

Data compiled by the National Treasury Secretariat (STN), a branch of the Brazilian Ministry of Finance, provide empirical evidence on the main sources of funds for metropolitan regions as well as on the differences existing among these municipalities, specially those between the core cities of metropolitan areas and other municipalities as a whole. ${ }^{3}$

As stated before, the municipal budget structure is affected by the size of a city's population. About $50 \%$ of the 66.5 million people living in metropoli- 
$\tan$ cities reside in 11 core cities with a population of over one million people. If we take the metropolitan cities with more than 500 thousand inhabitants, the degree of concentration of the metropolitan population goes up to two thirds. This concentration tends to grow as municipalities around the core cities have experimented higher rates of population increase in recent times. As we shall see, the latter are those less favored by federal transfers.

Metropolitan cities respond for $50 \%$ of total municipal revenue. Particular features regarding the revenue composition of metropolitan cities - core and non-core cities - as well as of nonmetropolitan municipalities are stressed below (see table 1):

- Core cities of metropolitan regions rely mostly on their own taxes, mainly the Tax on Services (ISS). They also receive a significant amount from shared taxes, especially from their share in ICMS, the state valueadded tax collected within their territorial limits. Despite concentrating two thirds of the metropolitan population, the money they receive from other transfers is less significant compared with non-core metropolitan cities and other municipalities. ${ }^{4}$ It's worth noting the small amount of credit operations (R \$ 538 million included in "other revenues" $)^{5}$ and of discretionary capital transfers, both going mainly to nonmetropolitan cities.

- Own revenues are much lower in non-core metropolitan cities. First, the ISS applies to a smaller tax base (some cities attract service companies by reducing the tax rate to a minimum). Although the Urban Land and Property Tax prevails, peripheral cities host large numbers of poor people living in unregistered substandard houses. Less valued buildings and informal transactions explain the lower collection of the Real Estate Conveyance Tax (ITBI). Altogether, these facts lead to a much lower per capita tax collection than that of the core cities. Although fees are relatively more important than in core cities, they are negligible in absolute terms, besides being sometimes subject to a constitutionally supported ban.

- The preeminence of the share in ICMS in total revenues of non-core municipalities reflects the fact that medium size cities peripheral to major centers are more likely to host industries and have a large range of commercial activities. Their share in federal taxes, through the $\mathrm{Mu}-$ 
nicipalities Participation Fund (FPM) is also significant, even though the criteria applied for distributing the FPM is biased towards less populated municipalities (which is the reason for nonmetropolitan cities receiving twice the amount transferred to non-core metropolitan ones). As a whole, the FPM is less important for these municipalities than the transfers earmarked to education and health, which are directly related to population and services provided. Capital grants are important to investments, given the difficulties to assess credit, but, being discretionary, these transfers are inadequate for financing longterm big projects in urban infrastructure.

- For nonmetropolitan cities, own revenues account for only $16 \%$ of their available tax revenues. ${ }^{6}$ Generally smaller than the previous ones, they rely strongly on transfers, not only to provide services but also to invest. The FPM is their major revenue source. Their share in ICMS, which ranks second in importance, benefits from a preferential treatment enjoyed by nonmetropolitan municipalities in the state legislation that controls one fourth of the ICMS allocated to the municipalities (see box 1). The extent of the responsibility of local governments for elementary education explains the large sum they receive under the Fundef. Capital grants are extremely significant for municipalities with less than 50 thousand inhabitants (90\% of the Brazilian cities).

Per capita transfers to small metropolitan cities (inside and outside the revenue sharing system) may be 33 times higher than the amount of taxes and fees they collect. As an average, the same ratio is 1.4 for core and 3.6 for non-core cities, respectively, going up to 8.6 for nonmetropolitan municipalities. As a result, total per capita revenues of medium size and some big metropolitan cities may be $40 \%$ below the per capita revenues of nonmetropolitan cities with less than five thousand inhabitants. ${ }^{7}$

Differences in per capita revenues, due to distortions accumulated over time in revenue sharing and other intergovernmental transfers (see table 2), represent an obstacle to cooperation in matters of common interest in metropolitan areas.

Differences in the composition of metropolitan financing also reflect the huge regional disparities existing in Brazil. Whereas in core cities in the developed Southeast region own revenues cover about half of their budget, 
core cities in the less developed North and Northeast regions rely heavily on shared revenues and other transfers (see table 3 ).

On the expenditure side, the figures also reveal important differences. Table 4 shows the breakdown of municipal expenditures and the budget results - current and total — for the 2002 fiscal year, and table 5 sets forth the sources of investment financing. They show that metropolitan cities relied basically on savings to finance investments: current savings responded for $70 \%$ of total investments. For major core cities, credit operations were the second most important source, whereas capital transfers played that role for other metropolitan cities (in metropolitan cities with less than 20 thousand inhabitants, capital transfers respond for $40 \%$ of investments).

\section{MAIN OBSTACLES TO METROPOLITAN FINANCING}

The main obstacles to metropolitan financing can be classified as follows:

- obstacles to achieve and sustain cooperation and integration of public investments and services in the metropolitan region;

- obstacles to better explore the local tax basis and to access external sources of financing;

- obstacles to control the allocation of resources applied in the region;

- obstacles to increase the participation of the private sector in the financing and provision of services.

An inadequate institutional arrangement is an important obstacle to cooperation and integration of investments and services in the metropolitan areas. Under the present constitutional framework, there is no possibility of enforcing or even creating effective mechanisms for inducing joint efforts to improve working and living conditions in a metropolitan area. The conditions required for state governments to set up metropolitan regions are not much help, since different services - like water provision, sewage systems and health services - have specific spatial configurations, meaning that interests, benefits and the willingness of each municipality to perform common tasks will be different. Thus, the state legislation is able to define the composition of the metropolitan region, set some directives, call for coordination, and create a specific body to design a good plan for the whole region, but lacks the power to put into place the instruments needed to implement the actions contemplated in the plan. 
Effective commitment to work together depends on the determination of mayors and governors to overcome political rivalries. Formal agreements can be established, but cannot function properly without the power to interfere in public policies in the region. Any attempt to provide the metropolitan body with decision making power conflicts with the political autonomy of the municipalities and the desire of the state governors to exercise political influence in what quite often is the most important part of the state territory. ${ }^{8}$

The interference of the federal government makes the political situation more complex. The proliferation of political parties as well as the distinct coalitions formed at the federal, state and local levels to support their respective administrations, increase the power of municipal governments when they are supported by the same coalition that supports the federal government. The mayors of the big metropolitan cities and the corresponding state governors quite often compete over who can exercise greater influence in the whole metropolitan area.

Cooperation and integration in the metropolitan areas are also constrained by the legal provisions that determine the distribution of resources in those areas. As noted in the previous sessions, the formula applied to the sharing of tax revenues, together with other rules designed to transfer federal money to state and local governments, conduce to a high degree of inequality in per capita budgets in a given metropolitan region. These huge differences increase the political resistance to cooperation, as richer municipalities may find little incentive to contribute to investments outside their limits, whereas poorer ones may find it easier to stimulate their population to look for better services in neighboring cities.

This should not be understood as a call for a return of the strong centralized institutional arrangement prevailing before the 1988 Constitution. Nevertheless, it's worth remarking the virtual absence of federal support, not only in financing, but also in providing an institutional framework for urban development. Despite provision set forth in article 23 of the 1988 Constitution for cooperation between the federal, state and municipal governments in policies and programs to address problems in housing and sewerage, for instance, regulation is still pending. 
Proposals for increasing tax effort at the local level miss the point. Besides the increase in federal and state transfers following the 1988 Constitution, municipalities, specially the big ones, have succeeded in better exploring their own tax bases and raising fees in an unfavorable environment characterized by a very high ratio of the overall tax burden. Further increases tend to be relatively small, even though credit lines from official banks for tax management improvement may be of some help.

Access to external financial sources is an important political issue. With reference to fiscal resources, discretionary transfers and direct application of federal or state funds in the region can be seen as an important obstacle to improving efficiency in metropolitan financing. The ability of each municipality in the region to get money from the federal or state budget depends on political relationships. We can envisage four possible situations, which are depicted below:

The best situation is one in which the local administration is supported by the same coalition that supports both state and federal governments. The opposite case occurs when the local government is politically misaligned, at the same time, with the state and federal governments. Of the two remaining alternatives, the most favorable is the one in which the municipal government goes along with the political line of the federal government, as direct relationships between the federal and local governments have gained more attention in the recent past.

Another political problem affecting metropolitan finances is the rules applied for sharing federal and state taxes with the municipalities. In relation to the ICMS, metropolitan municipalities usually get a less favorable treatment in the state legislation that governs the partition of one fourth of the amount that belongs to all municipalities in the same state.

Legal provisions concerning the share of the Federal Income Tax (IR) and the Tax on Industrialized Products (IPI) going to the municipalities (see box 1) also affects metropolitan finances. According to the 1988 Constitu-

Intergovernmental Relations Patterns9

\begin{tabular}{cccc}
\hline & & \multicolumn{2}{c}{ States relations to the federal government } \\
\cline { 2 - 3 } & & Aligned & Not aligned \\
\hline Municipalities relations & Aligned & Very good & Good \\
\cline { 2 - 4 } to the federal government & Not aligned & Very bad & Bad \\
\hline
\end{tabular}


tion, proceedings from these taxes forming the Municipalities Participation Fund (FPM) are split in two - with one part going to the state capital municipalities (who get $10 \%$ of the FPM), and the other to all the remaining municipalities (90\% of the FPM). Moreover, the criteria applied for setting the individual shares is biased toward the smaller municipalities. As a consequence, the ten most important metropolitan areas, ${ }^{10}$ which house $30 \%$ of the Brazilian population and $68 \%$ of the electorate, generating around $50 \%$ of the country's GDP, got only $12.7 \%$ of the FPM in 2002 .

Limits to borrowing should also be mentioned, even though they are important to avoid mismanagement of public accounts. Total indebtedness of the Brazilian municipalities is not expressive (less than five percent of the net public debt as a whole), but is highly concentrated - around 75\% of it is the responsibility of three major cities: São Paulo, Rio de Janeiro and Salvador. Big municipalities aside, the main constraint on borrowing set by the Senate and by the Central Bank for other municipalities is not legal in nature. Limits on credit extended to municipalities, together with the bureaucratic requirements to be met by the borrower, are the real barriers, specially for medium size and smaller municipalities, whose debts are generally low in relation to current revenues.

For big municipalities, the point to be raised is the possibility of introducing dynamic considerations in setting limits to finance investments through borrowing. Annual limits that obey the Gregorian calendar lead to lower investments in bad times, as current revenues fall and vice versa. Thus, investments that may contribute to impulse recovery or to mitigating the negative social impacts of unemployment have to be postponed in times when they are mostly needed. Applying multiyear's averages, for instance, could be an alternative, when there is no risk of this putting the fiscal situation out of control. The possibility of pooling resources from metropolitan municipalities to increase its creditworthiness should also be considered.

From another standpoint, the individual limits to borrowing may contribute to an inefficient allocation of investments in the metropolitan area, as richer municipalities may get additional money to finance investments of less priority from a metropolitan perspective.

Efficiency in metropolitan financing also suffers from the earmarking of revenues and other conditionalities to the allocation of municipal resources. 
The above mentioned disparities in the money allocated to specific purposes in a given metropolitan area may lead to a waste of resources. It could be easily demonstrated that individual obligations to spend a fixed percentage of the local resources in health and education, for instance, will not equilibrate needs and means in the metropolitan space, notwithstanding the importance of having guarantees for social spending in the region as a whole.

Increasing private sector participation in metropolitan financing requires an improvement in regulations that face political and institutional obstacles. From a political point of view, there is a widespread sentiment that the transfer of services with important social implications to private hands, via concessions or privatizations, may obstruct the access of low income families to basic needs, as they won't be able to pay the tariffs required for a fair remuneration of the capital invested. Politicians are, therefore, very careful to push for an increased role of private investors in more sensitive areas, such as sanitation.

Improving regulations is a political as well as an institutional problem. The Brazilian Constitution empowers local governments to grant concessions for the provision of services of local interest, such as public transportation and waste collection and disposal. The power to concede transportation across municipal boundaries and distribution of gas is in the state's hands. The federal government detains the power to grant concessions in areas such as electric power, telecommunications and interstate transportation, among others.

Water supply and sewage are a case in point. Concessions handed over from the municipalities to state owned companies in the mid seventies are now a big unsolved problem, since local and state governments argue about who should be in charge of regulating these services in metropolitan areas. To make things more complicated, the Constitution entitles the federal government to set general directives related to sanitation, and declares that the federal government, the states and the municipalities are competent for developing programs to improve sanitation conditions. A bill proposing new federal legislation to settle the situation has been under discussion in the national Parliament for some time now, but despite pressures for a rapid approval, no final agreement has been reached yet. 
Legal obstacles also affect the integration of urban transportation, insofar as state and municipal bodies would have to work together to implement a joint plan for the transportation network that would contribute to a better organization of the metropolitan space, as well as to a more efficient circulation of goods and people in the region.

Other important contribution to metropolitan financing could come from the opening up of the local public sector financial market to private financial institutions. Apart from short-term loans to be repaid using tax revenues of the same fiscal year - known as ARO operations - , private banks are not willing to supply credit to finance public investments at the local level, due to local governments' lack of credibility and to mistrust in local finances, besides legal difficulties for the cities to grant adequate guarantees. ${ }^{11}$ Two conditions may now create a more favorable environment for the development of a private credit market for local governments: the monetary stabilization and the provisions of the Fiscal Responsibility Law. Both will lead to transparency and credibility of local public accounts.

\section{EMERGENCE OF NEW PROPOSALS FOR IMPROVING COORDINATION}

Under present financial constraints, new proposals for dealing with the problem of metropolitan financing aimed at improving efficiency in allocation through better coordination of public interventions in the metropolitan area. These proposals, developed in the mid nineties, called for a more effective participation of the municipalities and a wider involvement of society, NGOs, and private sector representatives.

New experiences included voluntary associations of municipalities to deal with one or more issues - such as garbage collection, health and transportation -, or to develop projects related to the multiple use of water resources through the institution of water basin committees. In the state of Minas Gerais, $92 \%$ of the municipalities were involved in health consortia (Farah, 2001, apud Rolnik). It's worth noting the federal incentive to the health system organization that counts on stable and significant transfers of resources to subnational governments.

The new provisions of the 1988 Federal Constitution required the states to adapt their own constitutions (Azevedo, 1999). Nevertheless, there's great variety in the way the states deal with the issue of metropolitan regions, when 
they do. Neither the requirements for the institution of a new region nor the common interest functions are always clearly defined. Although attention is generally paid to the way municipalities and their populations participate in the process of instituting metropolitan regions, just a few states stress the importance of state participation itself. The fundamental aspect of financing the common projects and activities is not adequately dealt with, which is partly explained by the difficulties raised in section 4 .

The state of São Paulo, with three metropolitan regions hosting more than 22 million people, has been improving its model for metropolitan cooperation. The São Paulo metropolitan region, now with 39 municipalities, was created in 1973, with cities that form an industrial belt around the capital city of São Paulo. The "Baixada Santista," a group of nine municipalities under the influence of the most important Brazilian harbor, was established in 1996, followed by the Campinas metropolitan region, in 2000. The latter region encompasses 19 cities. The regions' participation in the state GDP is $47.6 \%, 3.6 \%$ and $12 \%$, respectively. ${ }^{12}$ Their net revenue in 2002 accounted for $34 \%$ of total revenues for all Brazilian metropolitan regions.

An amendment to the Constitution of the state of São Paulo, enacted in 1994, defined not only the public entities involved in management and the participation of the population in the management process, but also the requirements to set up a Development Fund and a Development Agency (Hotz, 2000). At the Metropolitan Development Council, with normative and executive functions, municipalities had the same number of seats as the state, regarding the common interest functions. In Campinas, the $\mathrm{Mu}-$ nicipal City Council also participates in a Consultative Committee for the whole region.

The $\mathrm{ABC}$ consortium — Região do Grande $\mathrm{ABC}$ - , home of the motor vehicle industry, was created by the initiative of seven Southeastern municipalities in the São Paulo metropolitan region to face together the common challenge of industrial restructuring in the area. Initially focused on the management of water resources, the consortium expanded the ambit of its action to economic and social development, bringing new actors into the scene through the Citizenship Forum. Although the experience may have proved the importance of cooperation, the need to find a more sound solution to deal with financing, together with the need to improve the relation- 
ship with the state government as well as the participation of the municipal city councils, are pointed out by specialists as the reasons for not achieving better results (Rolnik, 2000).

Up in the Northeast, the Recife metropolitan area, formed by 14 municipalities responsible for $68 \%$ of the state GDP (Fidem, 2002), put out a strategic plan to design common policies for dealing with the challenges it will face in the next 12 years. Covering three administrations, the study included the participation of society in the discussion of possible strategies. In this region, the study made to appraise the joint financial capabilities of the metropolitan municipalities showed the potential to mobilize fiscal resources and to access domestic credit to cover part of the investments visualized in the strategic plan for the region. ${ }^{13}$

\section{CONCLUDING REMARKS}

Adopting mechanisms for better coordinating public actions in metropolitan areas is an obvious way to attenuate some of the obstacles to the improvement of metropolitan financing, but it's not enough to meet the challenges nor to improve significantly the competitiveness and the living conditions in the more important Brazilian metropolitan areas.

Even though Brazilian metropolitan cities invest a reasonable amount of their revenues - $10 \%$ on average — in absolute terms, the money applied is far from what would be needed to meet the demand for resources. Besides, the lack of incentives for cooperation induces an autarchic behavior that may jeopardize those cities' efforts to solve problems that have impact outside their borders. Moreover, the reliance on capital transfers of a once-off nature to fund investments is incompatible with the long-term nature of the infrastructure projects. Thus, to enhance metropolitan management, it will be necessary to discuss alternatives to create metropolitan funds that could provide the metropolitan institutions with means to induce a more effective cooperation in those regions.

Some suggestions for discussion are advanced here. The first refers to changes in the constitutional rules governing the revenue sharing mechanism. The decision to set aside a small fraction (10\%) of the municipal fund (FPM) for the states' capital municipalities, adopted in 1967 and maintained 
in 1988, is now an anachronism. Having one criterion for the state capitals and another for the other municipalities in the metropolitan areas is a major reason for the wide disparity in the spatial distribution of fiscal resources that has been evidenced before. It is time now to appraise alternatives for establishing a metropolitan fund in the proposed revision of the constitutional transfers scheduled for the next round of the tax reform process.

The same could be said of proposals for revising the rules concerning the sharing of the state value-added tax with their municipalities. In setting new rules for defining how much of the state tax belonging to local governments will be distributed according to a state law, special consideration should be given to problems of metropolitan financing.

On the credit side, a proposition that deserves further consideration refers to conditions to be attached to credit lines from federal financial institutions to finance investments in metropolitan areas. In important areas, from the viewpoint of better land use in the metropolitan space, such as urban infrastructure, transportation, housing and sanitation, demands from metropolitan municipalities should be appraised from a collective perspective only, in order to induce cooperation and integration in the provision of public services. This does not conflict with the autonomy of local governments, since each municipality involved in a given project would be liable only for the portion of credit pertaining to the investment located within its boundaries. (This suggestion raises the issue of providing joint guarantees - a matter that needs to be fully analyzed.)

Building a private financial market for public sector investments at the metropolitan level may require more time to consolidate. The new law under discussion in the national Parliament for stimulating public-private sector partnerships in projects of infrastructure may provide some room for private financial institutions to participate in financing metropolitan investments.

Finally, we should make an effort to move towards a more uniform standard for qualification of a metropolitan region. As we have seen before, some essential definitions related to the requirements to set a metropolitan region are still to be included in some of the states' constitutions. 


\section{ANNEX}

\section{BOX 1: BRAZILIAN FEDERALISM - MUNICIPAL TAX REVENUE AND THE REVENUE SHARING SYSTEM}

Brazilian municipalities are considered as members of the Federation, having the same status as the states. They have administrative and political autonomy, so they may institute taxes, fees and improvement charges. The Brazilian Constitution defines also a revenue sharing system through which a substantial amount of resources is added to the municipalities. Besides that, specific grants may cofinance programs and projects aiming at putting public policies (generally federal) into place, but also at attending to each city's specific priorities. Revenue sharing and specific grants relate the federal government to the states and municipalities, but also the states to the municipalities. The Federal District, Brasília, can collect taxes and receive transfers both as a state and as a municipality.

In 2002, total tax burden accounted for $35.9 \%$ GDP, of which $70.1 \%$ were collected by the federal government, $25.5 \%$ by the states' governments, and $4.4 \%$ by municipal governments. Available revenue - own revenue plus shared revenue - was distributed by the same levels of government as $60.5 \%, 24.7 \%$ and $14.8 \%$ of total tax burden.

\section{MUNICIPAL AND FEDERAL DISTRICT OWN REVENUE}

Tax on Services (ISS) - the main tax, collected mostly by major cities that host modern services. Cities with over 500 thousand people - 31 out of 5,507 municipalities - are responsible for two thirds of total collection.

Urban Land and Property Tax (IPTU) - being the most important tax in medium size cities, its collection is less concentrated than that of ISS. Municipalities have been trying to increase collection through revising registers and updating properties' valuation.

Real Estate Conveyance Tax (ITBI) - due in case of transferring real estate legal ownership.

Fees - municipalities usually charge fees for tax collection, street lighting maintenance, economic activity licenses, among others. The smaller the municipality, the greater the importance of fees collection. The Federal District, as well as the states, may also charge fees.

Improvement Charges - only a few municipalities, mainly in the South, effectively use those charges.

The Federal District may also charge state taxes: the collection of the most important one, the Tax on Goods, Intermunicipal Transportation and Communications Services (ICMS), a value-added tax, and of the Tax on Motor Vehicles (IPVA), represented 76.7\% of its total net revenue in 2002. 


\section{THE REVENUE SHARING SYSTEM}

Municipalities are entitled to :

- $25 \%$ of the state ICMS, shared among municipalities according to value added through operations in their territories ( $75 \%$ of the amount to be shared) and to state law ( $25 \%$ of the amount shared, generally in benefit of the poorest). From this transfer, $15 \%$ is credited to the Fundef (see below), and the remaining $85 \%$, directly to the municipalities;

- $50 \%$ of the state IPVA, levied on the motor vehicles licensed inside their jurisdiction;

- $22.5 \%$ of federal IPI and Income Tax (IR) collections, which form the Municipalities Participation Fund (FPM). The FPM is split in two parts - 10\% for the state capital municipalities, and the remaining $90 \%$ for the other ones. Municipalities assign 15\% of the FPM they receive to the Fundef (see below). The formula applied for sharing the FPM among Brazilian municipalities is biased in favor of the smaller ones;

- keep the total income tax withheld at the source on income payments made directly by them or by their autarchies and foundations (IRRF);

- $70 \%$ of the federal Financial Operations Tax - Gold (considered as a financial asset) (IOF-Ouro);

- $50 \%$ of the federal Tax on Rural Land and Property (ITR);

The Federal District is entitled to the Federal District and States Participation Fund (FPE), composed of $21.5 \%$ of the federal IPI and IR collection. From this transfers, $15 \%$ is assigned to the Fundef. It's also entitled to income tax withheld at the source (IRRF) and to $30 \%$ of the IOF-Ouro.

\section{BRAZILIAN REVENUE SHARING SYSTEM}

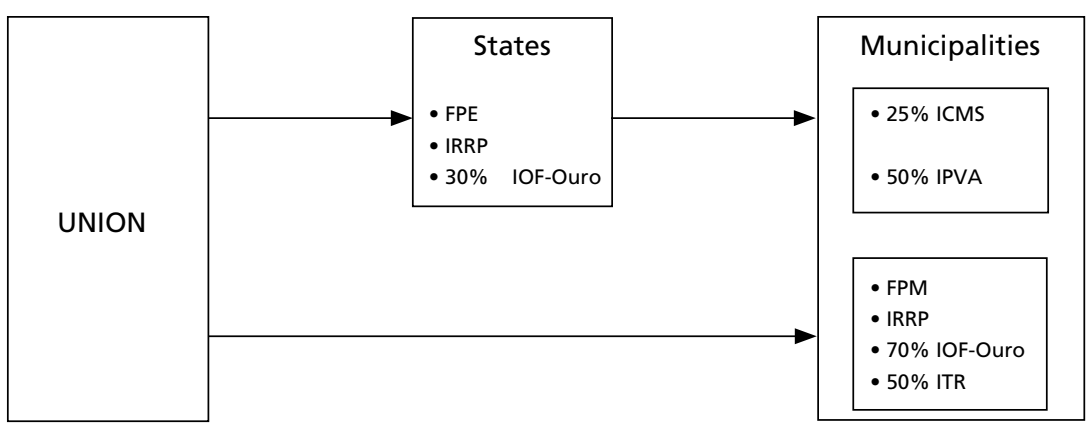




\section{BOX 2: COMPENSATION, COOPERATION AND DISCRETIONARY TRANSFERS}

- Export Compensation Fund (FPEx) - currently under revision, this fund aims at covering states' revenue losses from the exemption granted to exports from the states' VAT. It's distributed to the states in proportion to their participation on exports. States have to share $25 \%$ of this transfer with the municipalities, according to the same criteria used for the ICMS. States and municipalities have to assign $15 \%$ of their participation on FPEX transfers to the Fundef (see below).

- Royalties - states and municipalities are entitled to receive compensation for the exploitation of petroleum and natural gas, hydroelectricity and other mineral resources inside their territory or in the adjacent maritime platform.

- Fundef - a constitutional amendment (n.14/96) instituted an intergovernmental financial cooperation for improving elementary education. The fund is formed by earmarking percentages of transfers from the revenue sharing system, so as to guarantee a specified minimum amount of spending per student enrolled in public elementary schools all over the country. The sources of Fundef are the following: (a) 15\% of the municipal and states share in the ICMS; (b) 15\% of the FPM; (c) 15\% of the FPE; (d) 15\% of the municipal and states share in the FPEX. Fundef is distributed according to the number of students enrolled in municipal or state owned elementary schools. In case the money collected from the above sources is not enough to guarantee the minimum spending established by law, the federal government is responsible for providing supplementary transfers.

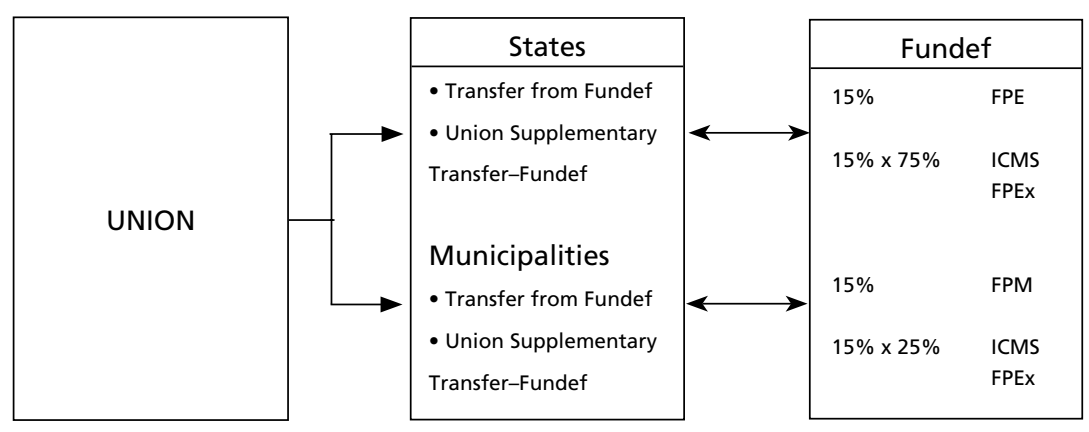

- Education Tax (Salário Educação) - an additional source for cooperation in financing the public elementary education comes from a payroll social contribution - known as "Salário Educação" - due by private companies.

- Health - Constitutional amendment n. 29/2000 earmarked federal, state and municipal revenues for jointly financing of basic health services and medical care. Each year, federal government expenditures must increase by an amount equal to the nominal GDP growth rate on previous fiscal year expenditures. Municipal governments must spend $15 \%$, and states and the Federal District, $12 \%$ of their own revenues plus constitutional transfers (FPE, FPM, ICMS etc). The money is transferred according to the population and to the nature of services provided. For medium size municipalities and for the bigger ones, transfers from the Health Fund may be much higher than those from the FPM.

- Social Assistance - the National Fund for Social Assistance attempts to impulse the decentralization of social assistance policies.

- Discretionary Transfers - these transfers arise out of allocations in the federal budget, which are mainly of a once-off nature and oriented to finance small-scale activities or investments at the local level. In small cities, they are a strong source to finance investments. 
Table 1: Brasil - Municipal Revenue

Metropolitan and Nonmetropolitan Cities, 2002

$\mathrm{R} \$$ millions

\begin{tabular}{|c|c|c|c|c|c|c|c|c|}
\hline & \multirow{2}{*}{\multicolumn{2}{|c|}{ TOTAL }} & \multicolumn{4}{|c|}{ METROPOLITAN REGIONS } & \multirow{2}{*}{\multicolumn{2}{|c|}{$\begin{array}{l}\text { NONMETROPO } \\
\text { LITAN CITIES }\end{array}$}} \\
\hline & & & \multicolumn{2}{|c|}{ CORE CITIES } & \multicolumn{2}{|c|}{ OTHER CITIES } & & \\
\hline Population (in thousands) & 158 & 884 & 38,9 & 915 & 27,6 & 546 & 92,3 & 23 \\
\hline REVENUES & Amount & $\%$ & Amount & $\%$ & Amount & $\%$ & Amount & $\%$ \\
\hline Total Net Revenue* & 106,930 & 100.0 & 36,741 & 100.0 & 16,575 & 100.0 & 53,613 & 100.0 \\
\hline Available Tax Revenue & 64,133 & 60.0 & 22,060 & 60.0 & 10,909 & 65.8 & 31,164 & 58.1 \\
\hline Own Taxes & 20,852 & 19.5 & 12,728 & 34.6 & 3,121 & 18.8 & 5,003 & 9.3 \\
\hline $\begin{array}{l}\text { Urban Land and Property } \\
\text { Tax - IPTU }\end{array}$ & 6,669 & 6.2 & 3,821 & 10.4 & 1,253 & 7.6 & 1,594 & 3.0 \\
\hline Tax on Services - ISS & 8,219 & 7.7 & 5,191 & 14.1 & 1,107 & 6.7 & 1,921 & 3.6 \\
\hline Real Estate Conveyance Tax - ITBI & 1,472 & 1.4 & 789 & 2.1 & 214 & 1.3 & 469 & 0.9 \\
\hline Other Taxes - Federal District & 1,980 & 1.9 & 1,980 & 5.4 & - & - & - & - \\
\hline Fees & 2,512 & 2.3 & 947 & 2.6 & 547 & 3.3 & 1,019 & 1.9 \\
\hline $\begin{array}{l}\text { Shared Tax Revenues } \\
\text { and Others** }\end{array}$ & 43,281 & 40.5 & 9,332 & 25.4 & 7,788 & 47.0 & 26,161 & 48.8 \\
\hline $\begin{array}{l}\text { Municipalities Participation } \\
\text { Fund - FPM }\end{array}$ & 16,291 & 15.2 & 1,261 & 3.4 & 1,955 & 11.8 & 13,075 & 24.4 \\
\hline $\begin{array}{l}\text { Participation on the Tax on Goods, } \\
\text { Intermunicipal Transportation and } \\
\text { Communication Services - ICMS }\end{array}$ & 20,440 & 19.1 & 5,074 & 13.8 & 4,835 & 29.2 & 10,531 & 19.6 \\
\hline $\begin{array}{l}\text { Participation on the Tax on } \\
\text { Motor Vehicles - IPVA }\end{array}$ & 3,300 & 3.1 & 1,512 & 4.1 & 498 & 3.0 & 1,289 & 2.4 \\
\hline $\begin{array}{l}\text { Federal Income Tax Withheld } \\
\text { at the Source - IRRF }\end{array}$ & 2,094 & 2.0 & 1,198 & 3.3 & 309 & 1.9 & 587 & 1.1 \\
\hline Other Transfers & 1,156 & 1.1 & 287 & 0.8 & 191 & 1.2 & 678 & 1.3 \\
\hline $\begin{array}{l}\text { Specific Grants and } \\
\text { Compensatory Transfers }\end{array}$ & 29,186 & 27.3 & 8,930 & 24.3 & 3,595 & 21.7 & 16,660 & 31.1 \\
\hline Health System - SUS & 6,249 & 5.8 & 2,349 & 6.4 & 643 & 3.9 & 3,256 & 6.1 \\
\hline Fund for Education - Fundef & 9,488 & 8.9 & 1,819 & 5.0 & 1,468 & 8.9 & 6,200 & 11.6 \\
\hline $\begin{array}{l}\text { Other Current Grants and } \\
\text { Compensatory Transfers }\end{array}$ & 9,669 & 9.0 & 4,437 & 12.1 & 961 & 5.8 & 4,271 & 8.0 \\
\hline Other Capital Grants & 3,780 & 3.5 & 324 & 0.9 & 523 & 3.2 & 2,933 & 5.5 \\
\hline Other Revenues & 13,611 & 12.7 & 5,750 & 15.7 & 2,071 & 12.5 & 5,789 & 10.8 \\
\hline
\end{tabular}

Sources: Ministry of Finance/National Treasury Secretariat

Notes:

- Includes the Federal District, Brasília

* Net of public servants' contributions to pension funds

** Includes IOF-Ouro, ITR and the Education Tax 
Table 2: Metropolitan and Nonmetropolitan Cities Per Capita Tax Revenue and Transfers by Range of Population, 2002

\begin{tabular}{|c|c|c|c|c|c|c|}
\hline \multirow{3}{*}{ RANGE } & \multicolumn{4}{|c|}{ METROPOLITAN REGIONS } & \multirow{2}{*}{\multicolumn{2}{|c|}{$\begin{array}{l}\text { NONMETROPOLITAN } \\
\text { REGIONS }\end{array}$}} \\
\hline & \multicolumn{2}{|c|}{ CORE CITIES } & \multicolumn{2}{|c|}{ OTHER CITIES } & & \\
\hline & OWN TAXES & TRANSFERS & OWN TAXES & TRANSFERS & OWN TAXES & TRANSFERS \\
\hline 0 to 5,000 & - & - & 27.4 & 915.5 & 34.2 & 928.9 \\
\hline 5,001 to 10,000 & - & - & 63.0 & 561.5 & 26.4 & 614.7 \\
\hline 10,001 to 20,000 & - & - & 51.3 & 469.5 & 24.2 & 498.3 \\
\hline 20,001 to 50,000 & - & - & 89.8 & 501.7 & 34.4 & 428.0 \\
\hline 50,001 to 100,000 & 80.1 & 363.9 & 92.4 & 456.1 & 57.0 & 387.6 \\
\hline 100,001 to 500,000 & 262.0 & 504.0 & 122.8 & 381.1 & 89.6 & 400.3 \\
\hline 500,001 to $1,000,000$ & 156.2 & 349.4 & 125.9 & 382.5 & 132.7 & 462.5 \\
\hline $1,000,001$ to $2,000,000$ & 213.7 & 426.2 & 148.6 & 385.0 & 128.9 & 348.8 \\
\hline Above $2,000,001$ & 388.9 & 493.7 & - & - & - & - \\
\hline
\end{tabular}

Sources: Ministry of Finance/National Treasury Secretariat Notes:

(1) Includes the Federal District

(2) Transfers include total intergovernmental transfers inside and outside the revenue sharing system 
Table 3: Brasil - Metropolitan Cities Per Capita Revenue by Geografic Region, 2002

\begin{tabular}{|c|c|c|c|c|c|c|c|c|c|c|}
\hline & \multicolumn{2}{|c|}{ MIDWEST } & \multicolumn{2}{|c|}{ NORTH } & \multicolumn{2}{|c|}{ NORTHEAST } & \multicolumn{2}{|c|}{ SOUTH } & \multicolumn{2}{|c|}{ SOUTHEAST } \\
\hline & CORE & OTHER & CORE & OTHER & CORE & OTHER & CORE & OTHER & CORE & OTHER \\
\hline & CITIES & CITIES & CITIES & CITIES & CITIES & CITIES & CITIES & CITIES & CITIES & CITIES \\
\hline $\begin{array}{l}\text { Population } \\
\text { (in thousands) }\end{array}$ & 3,180 & 1,431 & 1,323 & 556 & 8,664 & 3,670 & 4,995 & 5,893 & 20,754 & 16,095 \\
\hline Total Net Revenue* & $2,472.3$ & 385.9 & 442.2 & 250.0 & 510.7 & 504.2 & 957.1 & 552.4 & 919.8 & 669.7 \\
\hline Available Tax Revenue & $1,173.8$ & 204.0 & 258.6 & 126.5 & 292.7 & 339.9 & 479.1 & 339.3 & 629.1 & 453.5 \\
\hline Own Taxes & 872.8 & 33.9 & 95.7 & 25.9 & 132.1 & 62.0 & 246.0 & 74.4 & 359.1 & 148.6 \\
\hline $\begin{array}{l}\text { Urban Land and } \\
\text { Property Tax - IPTU }\end{array}$ & 77.0 & 16.0 & 15.6 & 2.9 & 32.2 & 13.8 & 76.7 & 24.8 & 139.4 & 64.1 \\
\hline Tax on Services - ISS & 134.0 & 9.6 & 46.0 & 11.6 & 68.5 & 34.7 & 108.5 & 25.1 & 172.0 & 50.5 \\
\hline $\begin{array}{l}\text { Real Estate Conveyance } \\
\text { Tax - ITBI }\end{array}$ & 23.2 & 4.2 & 2.1 & 0.2 & 7.8 & 3.3 & 24.9 & 6.2 & 25.1 & 9.9 \\
\hline $\begin{array}{l}\text { Other Taxes - Federal } \\
\text { District }\end{array}$ & 622.6 & - & - & - & - & - & - & - & - & - \\
\hline Fees & 16.0 & 4.1 & 31.9 & 11.2 & 23.7 & 10.2 & 35.8 & 18.3 & 22.6 & 24.2 \\
\hline $\begin{array}{l}\text { Shared Tax Revenues } \\
\text { and Others** }\end{array}$ & 301.0 & 170.1 & 162.9 & 100.6 & 160.5 & 277.9 & 233.1 & 264.9 & 270.0 & 304.9 \\
\hline $\begin{array}{l}\text { Municipalities } \\
\text { Participation } \\
\text { Fund - FPM }\end{array}$ & 43.3 & 99.4 & 79.4 & 44.9 & 62.6 & 98.0 & 41.2 & 88.6 & 13.0 & 56.3 \\
\hline $\begin{array}{l}\text { Participation on the Tax } \\
\text { on Goods, Intermunicipal } \\
\text { Transportation and } \\
\text { Communication Services } \\
\text { - ICMS }\end{array}$ & 57.8 & 59.5 & 66.0 & 35.6 & 79.7 & 168.7 & 128.7 & 141.5 & 167.2 & 203.6 \\
\hline $\begin{array}{l}\text { Participation on the Tax } \\
\text { on Motor Vehicles - IPVA }\end{array}$ & 16.6 & 4.5 & 12.8 & 4.1 & 11.3 & 5.3 & 40.7 & 17.4 & 55.0 & 22.8 \\
\hline $\begin{array}{l}\text { Federal Income Tax } \\
\text { Withheld at the Source } \\
\text { - IRRF }\end{array}$ & 120.1 & 3.5 & 4.8 & 1.6 & 6.8 & 5.4 & 20.3 & 6.3 & 31.3 & 15.3 \\
\hline Other Transfers & 63.2 & 3.2 & 0.0 & 14.4 & 0.1 & 0.5 & 2.3 & 11.1 & 3.6 & 6.9 \\
\hline $\begin{array}{l}\text { Specific Grants and } \\
\text { Compensatory } \\
\text { Transfers }\end{array}$ & $1,073.4$ & 168.1 & 144.3 & 111.9 & 150.4 & 132.8 & 219.0 & 142.1 & 141.1 & 122.3 \\
\hline Health System - SUS & - & 19.4 & 103.5 & 44.6 & 37.9 & 19.3 & 136.1 & 14.0 & 58.0 & 27.2 \\
\hline $\begin{array}{l}\text { Fund for Education } \\
\text { - Fundef }\end{array}$ & 17.3 & 49.9 & 14.9 & 21.3 & 20.0 & 48.9 & 49.1 & 68.7 & 63.9 & 49.8 \\
\hline $\begin{array}{l}\text { Other Current Grants and } \\
\text { Compensatory Transfers }\end{array}$ & $1,032.9$ & 58.1 & 20.1 & 23.8 & 75.1 & 33.7 & 25.6 & 42.1 & 16.8 & 30.6 \\
\hline Other Capital Grants & 23.2 & 40.7 & 5.7 & 22.2 & 17.4 & 30.9 & 8.3 & 17.3 & 2.4 & 14.7 \\
\hline Other Revenues & 225.1 & 13.7 & 39.4 & 11.6 & 67.5 & 31.4 & 259.0 & 71.0 & 149.5 & 93.9 \\
\hline
\end{tabular}

Sources: Ministry of Finance/National Treasury Secretariat

Notes:

- Includes the Federal District, Brasília

* Net of public servants' contributions to pension funds

** Includes IOF-Ouro, ITR and the Education Tax 
Table 4: Municipal Expenditures, Metropolitan and Nonmetropolitan Cities, 2002

$R \$$ millions

\begin{tabular}{|c|c|c|c|c|c|c|c|c|}
\hline & \multirow{2}{*}{\multicolumn{2}{|c|}{ TOTAL }} & \multicolumn{4}{|c|}{ METROPOLITAN REGIONS } & \multirow{2}{*}{\multicolumn{2}{|c|}{$\begin{array}{l}\text { NONMETROPOLI- } \\
\text { TAN REGIONS }\end{array}$}} \\
\hline & & & \multicolumn{2}{|c|}{ CORE CITIES } & \multicolumn{2}{|c|}{ OTHER CITIES } & & \\
\hline & Amount & $\%$ & Amount & $\%$ & Amount & $\%$ & Amount & $\%$ \\
\hline Total Net Expenditure & 105,952 & 100.0 & 36,874 & 100.0 & 16,215 & 100.0 & 52,863 & 100.0 \\
\hline Net Current Expenses & 20,852 & 19.5 & 12,728 & 34.6 & 3,121 & 18.8 & 5,003 & 9.3 \\
\hline Personnel* & 6,669 & 6.2 & 3,821 & 10.4 & 1,253 & 7.6 & 1,594 & 3.0 \\
\hline Interest Expenses & 8,219 & 7.7 & 5,191 & 14.1 & 1,107 & 6.7 & 1,921 & 3.6 \\
\hline Other Current Expenses & 1,472 & 1.4 & 789 & 2.1 & 214 & 1.3 & 469 & 0.9 \\
\hline Capital Expenditure & 15,890 & 15.0 & 4,307 & 11.7 & 2,691 & 16.6 & 8,892 & 16.8 \\
\hline Investments** & 13,979 & 13.2 & 3,603 & 9.8 & 2,342 & 14.4 & 8,034 & 15.2 \\
\hline Amortization & 1,910 & 1.8 & 704 & 1.9 & 348 & 2.1 & 858 & 1.6 \\
\hline Other Capital Expenditure & - & - & - & - & - & - & - & - \\
\hline Superavit / Deficit Current & 11,893 & & 3,070 & & 2,450 & & 6,373 & \\
\hline Total Superavit / Deficit & 978 & & (133) & & 360 & & 750 & \\
\hline
\end{tabular}

Sources: Ministry of Finance/National Treasury Secretariat

Notes:

* Payments to retirees are net of public servants contribution

** Includes investments in securities of state-owned companies

Table 5: Metropolitan and Nonmetropolitan Cities Investments and Sources of Funds, 2002

$R \$$ millions

\begin{tabular}{|c|c|c|c|c|c|c|c|c|}
\hline & \multirow{2}{*}{\multicolumn{2}{|c|}{ TOTAL }} & \multicolumn{4}{|c|}{ METROPOLITAN REGIONS } & \multirow{2}{*}{\multicolumn{2}{|c|}{$\begin{array}{c}\text { NONMETROPOLI- } \\
\text { TAN REGIONS }\end{array}$}} \\
\hline & & & \multicolumn{2}{|c|}{ CORE CITIES } & \multicolumn{2}{|c|}{ OTHER CITIES } & & \\
\hline & Amount & $\%$ & Amount & $\%$ & Amount & $\%$ & Amount & $\%$ \\
\hline Total Net Revenue* & 13,979 & 100.0 & 3,603 & 100.0 & 2,342 & 100.0 & 8,034 & 100.0 \\
\hline \multicolumn{9}{|l|}{ Sources of Funds } \\
\hline External Sources & 4,510 & 32.3 & 863 & 23.9 & 555 & 23.7 & 3,092 & 38.5 \\
\hline Credit Operations & 730 & 5.2 & 538 & 14.9 & 33 & 1.4 & 159 & 2.0 \\
\hline Capital Transfers & 3,780 & 27.0 & 324 & 9.0 & 523 & 22.3 & 2,933 & 36.5 \\
\hline Internal Sources & 9,469 & 67.7 & 2,741 & 76.1 & 1,787 & 76.3 & 4,941 & 61.5 \\
\hline Sale of Assets & 128 & 0.9 & 17 & 0.5 & 34 & 1.4 & 77 & 1.0 \\
\hline Other Capital Revenues & 337 & 2.4 & 225 & 6.2 & 12 & 0.5 & 100 & 1.2 \\
\hline Current Surplus & 9,005 & 64.4 & 2,366 & 65.7 & 1,742 & 74.3 & 4,765 & 59.3 \\
\hline Deficit & - & & 133 & 3.7 & - & & - & \\
\hline
\end{tabular}

Sources: Ministry of Finance/National Treasury Secretariat

* Includes investments in securities of state-owned companies 


\section{NOTES}

1. Araújo, 1996, p. 66.

2. And also urban agglomerations and micro regions - Article 25 of the 1988 Constitution.

3. As it may affect financial administration, it should be noted that the 2002 fiscal year is the second of the four year term for the present local administrations - 2001/2004.

4. To appraise the contribution of specific grants and other transfers to the budgets of core cities in metropolitan areas, we have to exclude from its total the $\mathrm{R} \$ 2.9$ bi that finance special activities of the Federal District.

5. Other revenues include short-term financial gains that are concentrated in the major cities and tend to decrease as the administration approaches its term.

6. The available tax revenues comprise own taxes and shared tax revenues. Own taxes represent $57.7 \%$ of available tax revenues for core cities and $28.6 \%$ for other cities in metropolitan regions (see table 1 ).

7. In the sample studied, the 70 non-core cities with 100 thousand to one million inhabitants have average total per capita revenue of $\mathrm{R} \$ 579.00$. The four core cities with 500 thousand to one million inhabitants are close to $\mathrm{R} \$ 608.00$. For the 1,136 nonmetropolitan cities with less than five thousand inhabitants, this amount reaches an average of $\mathrm{R} \$ 1,025.00$.

8. The metropolitan area of Rio de Janeiro accounts for two thirds of the state's GDP, population and electorate. In São Paulo, these same ratios are above 50\%.

9. The possible combinations referring to the political alignment with the federal government include the coalition that has power in Congress over the federal budget.

10. São Paulo, Rio de Janeiro, Belo Horizonte, Porto Alegre, RIDE - DF, Salvador, Curitiba, Recife, Belém and Fortaleza.

11. According to article 167 of the Federal Constitution, binding tax revenues are restricted to the revenue sharing system, to specific allocations of funds to health and education expenditures, to the ARO operations, to the granting of a guarantee or a counter-guarantee to the Union, and to the payment of debits owed to the same.

12. EMPLASA - www.emplasa.gov.br.

13. The result of this study showed that, under favorable assumptions, total savings by municipalities in the Recife metropolitan area could reach an yearly average of R\$ $195 \mathrm{mi}$ for the $2002-2006$ period. This potential to invest could be doubled if they were able to fully explore the limits to indebtedness (see Rezende and MacDowell, 2001; and Rezende, MacDowell and Miranda, 2002).

\section{REFERENCES}

ALVES, A. C. (1998) "Regiões metropolitanas, aglomerações urbanas e microrregiões: novas dimensões constitucionais da Organização do Estado Brasileiro”. Revista da Procuradoria Geral do Estado de São Paulo, ed. especial, São Paulo, set. 
ARAÚJO FILHO, V. (1996) “Antecedentes político-institucionais e a questão metropolitana no Brasil”. In: E. Dezouzart e V. Z. Zveibil (org.), Gestão metropolitana: experiências e novas perspectivas. 1. ed. Rio de Janeiro: Ibam, p. 49-70.

AZEVEDO, S., GUIA, V. R. M. (1999) A questão metropolitana no processo de reforma do Estado no Brasil. Available at: www.crab.rutgers.edu.

FIDEM, Secretaria de Planejamento e Desenvolvimento Social do Governo do Estado de Pernambuco. (2002) Estratégia de desenvolvimento da Região Metropolitana do Recife (2003/2015). Technical version. Recife, ago.

HOTZ, E. F. (2000) “A organização metropolitana Pós-Constituição de 1988”. Revista São Paulo em Perspectiva, 14 (4), São Paulo.

—, MACDOWELL, C. (2001) Desequilíbrios fiscais e cooperação intergovernamental na Região Metropolitana do Recife. BID/ IEPA/ FIDEM (mimeo).

—, MACDOWELL, C., MIRANDA, R. (2002) Região Metropolitana do Recife: potencial de recursos públicos para o financiamento do Plano Estratégico de Desenvolvimento. BID/IPEA/ FIDEM/ (mimeo).

ROLNIK, R., SOMEKH, N. (2000) “Governar as metrópoles: dilemas da recentralização”. Revista São Paulo em Perspectiva, 14 (4), São Paulo.

SECRETARIA DO TESOURO NACIONAL, Ministério da Fazenda. (2004). Available at: www.stn. fazenda.gov.br, data available in jan.

TRIBUNAL SUPERIOR ELEITORAL - TSE. (2004) Available at: www.tse.gov.br, data available in Jan. 